\title{
SLUDGE BATCH 5 (SB5): SELECTION OF CANDIDATE FRITS AND CHARACTERIZATION OF PRELIMINARY GLASS SYSTEMS
}

K.M. Fox

T.B. Edwards

D.R. Best

I.A. Reamer

R.J. Workman

July 2007

Materials Science and Technology Savannah River National Laboratory Aiken, SC 29808

Prepared for the U.S. Department of Energy Under Contract Number DEAC09-96SR18500

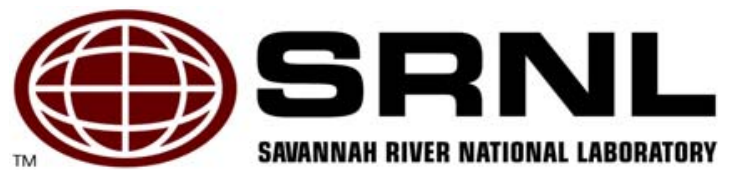


WSRC-STI-2007-00418

Revision 0

\section{DISCLAIMER}

This report was prepared by Washington Savannah River Company (WSRC) for the United States Department of Energy under Contract No. DE-AC09-96SR18500 and is an account of work performed under that contract. Neither the United States Department of Energy, nor WSRC, nor any of their employees makes any warranty, expressed or implied, or assumes any legal liability or responsibility for the accuracy, completeness, or usefulness, of any information, apparatus, or product or process disclosed herein or represents that its use will not infringe privately owned rights. Reference herein to any specific commercial product, process, or service by trademark, name, manufacturer or otherwise does not necessarily constitute or imply endorsement, recommendation, or favoring of same by WSRC or by the United States Government or any agency thereof. The views and opinions of the authors expressed herein do not necessarily state or reflect those of the United States Government or any agency thereof.

\section{Printed in the United States of America \\ Prepared For U.S. Department of Energy}

The Savannah River National Laboratory is operated for the U.S. Department of Energy by Washington Savannah River Company. 


\section{SLUDGE BATCH 5 (SB5): SELECTION OF CANDIDATE FRITS AND CHARACTERIZATION OF PRELIMINARY GLASS SYSTEMS}

K.M. Fox

T.B. Edwards

D.R. Best

I.A. Reamer

R.J. Workman

July 2007

Materials Science and Technology Savannah River National Laboratory Aiken, SC 29808 


\section{REVIEWS AND APPROVALS}

\section{AUTHORS:}

K.M. Fox, Materials Science and Technology

Date

T.B. Edwards, Statistical Consulting Section

Date

D.R. Best, Process Science and Engineering

Date

I.A. Reamer, Process Science and Engineering

Date

R.J. Workman, Process Science and Engineering

Date

\section{TECHNICAL REVIEWERS:}

D.K. Peeler, Process Science and Engineering

Date

\section{APPROVERS:}

C.C. Herman, Manager, Process Engineering Technology

Date

R.E. Edwards, Manager, Process Science and Engineering

Date

J.E. Occhipinti, Manager, Process Cognizant Engineering

Date

Waste Solidification Engineering 


\section{EXECUTIVE SUMMARY}

Six potential frits were identified as candidates for processing the February 2007 projected SB5 composition (i.e., no implementation of aluminum dissolution) from an array of frit formulations based upon composition-property model predictions. Test glasses were fabricated in the laboratory to verify the applicability of the product performance models to glasses produced with these frits.

Characterization of the glasses fabricated with the selected frits showed that all of the glasses had durability responses that are considered very acceptable at a waste loading of $36 \%$. The durability responses were predictable by the free energy of hydration models. No crystallization was identified in the quenched glasses. Samples of the glasses that were slowly cooled following the canister centerline cooled (ccc) thermal profile were found to contain small amounts of magnetite. This crystalline phase had little impact on the durability of the glasses, and therefore is not an issue for concern based on the February 2007 projections. Note that revised versions of the SB5 flowsheet, including those incorporating aluminum dissolution, are expected, which will require additional frit development work when received.

Initial melt rate testing results showed that the previously identified trend of increasing melt rate with increasing concentration of $\mathrm{B}_{2} \mathrm{O}_{3}$ for SB4 may be extended to this SB5 system. A complete report on melt rate testing with these frits will be issued at a later date. 


\section{TABLE OF CONTENTS}

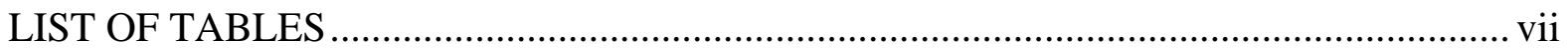

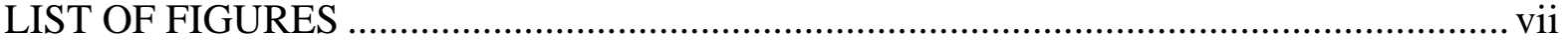

LIST OF ABBREVIATIONS ......................................................................................... viii

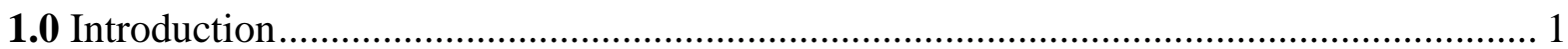

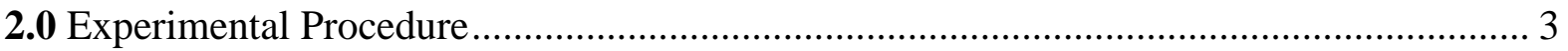

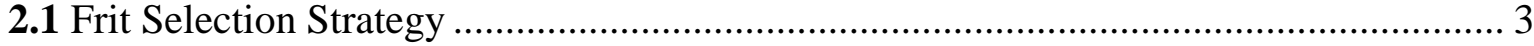

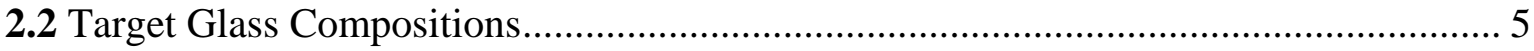

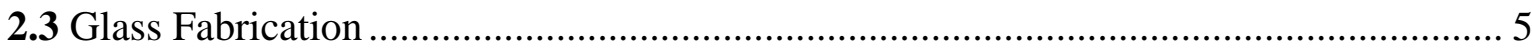

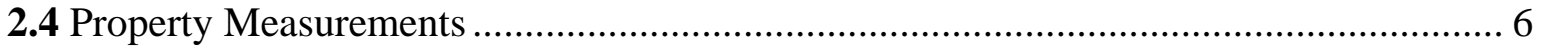

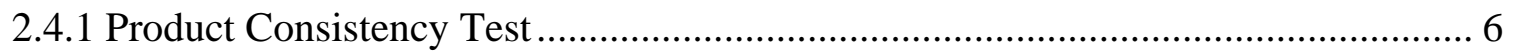

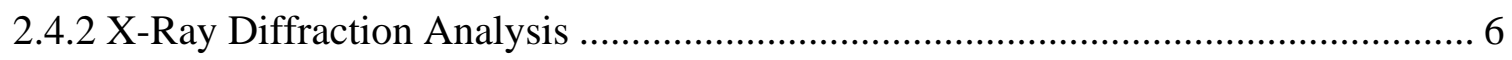

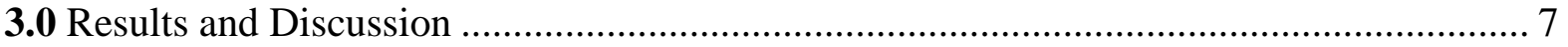

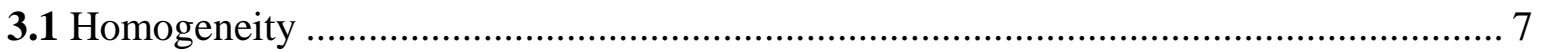

3.2 Product Consistency Test ................................................................................ 7

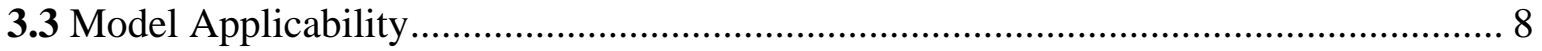

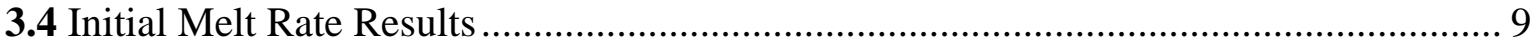

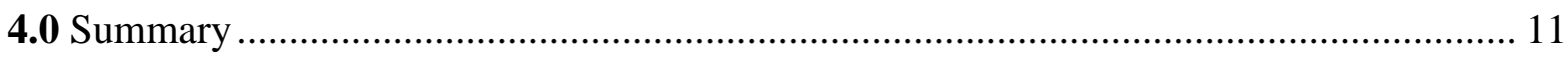

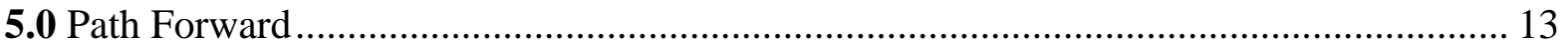

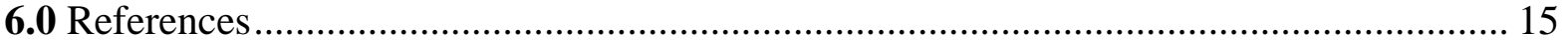




\section{LIST OF TABLES}

Table 2-1. Projected SB5 composition (in wt\% oxides), renormalized to exclude the radioactive

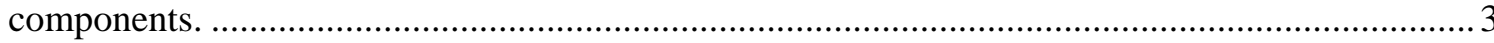

Table 2-2. Frit components and their concentration ranges used for MAR assessments..................... 4

Table 2-3. Composition of the six frits selected for MRF testing (in wt\% oxides) and their MAR

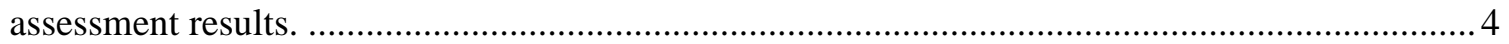

Table 2-4. Target compositions of the six test glasses (in wt $\%$ oxides) .............................................. 5

Table 3-1. Visual observations and XRD results for the quenched and ccc version of each glass. ...... 7

Table 3-2. PCT results for each of the test glasses and the standards. .............................................. 8

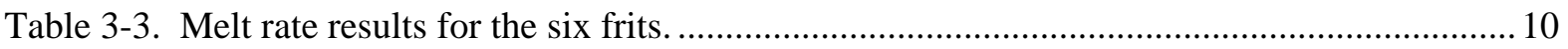

\section{LIST OF FIGURES}

Figure 3-1. Comparison of the Measured PCT Responses and the Durabilities Predicted by the Free

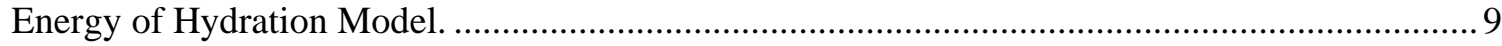




\section{LIST OF ABBREVIATIONS}

$\mathrm{AD}$

ARM

ARP

CCC

CSSX

del Gp

$\Delta \mathrm{G}_{\mathrm{P}}$

DWPF

EA

LWO

MAR

MCU

MRF

MST

PCCS

PCT

PSAL

SB4 / SB5

SRAT

SRNL

WL

XRD
Analytical Development

Approved Reference Material

Actinide Removal Process

canister centerline cooled

Caustic Side Solvent Extraction

Free Energy of Hydration

Defense Waste Processing Facility

Environmental Assessment

Liquid Waste Organization

Measurement Acceptability Region

Modular CSSX Unit

Melt Rate Furnace

monosodium titanate

Product Composition Control System

Product Consistency Test

Process Science Analytical Laboratory

Sludge Batch 4 / Sludge Batch 5

Slurry Receipt and Adjustment Tank

Savannah River National Laboratory

Waste Loading

X-ray Diffraction 
WSRC-STI-2007-00418

Revision 0

\subsection{Introduction}

Sludge Batch 5 (SB5) is the next sludge batch to be qualified for processing at the Defense Waste Processing Facility (DWPF). A sludge batch is defined as a single tank of sludge or a combination of sludges from different tanks that has been or will be qualified for transfer to DWPF. SB5 will consist primarily of Tank 51 - Sludge Batch 4 (SB4), which has already been qualified, and smaller portions of material from Tanks 5, 6, and 7. SB5 is also anticipated to contain monosodium titanate (MST)/sludge solids from the Actinide Removal Process (ARP) and cesium strip effluent from the Modular Caustic Side Solvent Extraction (CSSX) Unit (MCU). However, the work described in this report does not take the addition of these latter two waste streams into consideration.

Prior to the processing of a new sludge batch in DWPF, the Savannah River National Laboratory (SRNL) must analyze and confirm that the sludge batch produces an acceptable glass via durability models of the Product Composition Control System (PCCS). An integral part of this qualification process is the development of a frit, which when coupled with the sludge, produces an acceptable glass and maximizes waste throughput (which is dependent upon waste loading and melt rate).

The objectives of this task are scoping in nature and are intended to provide guidance for frit development efforts at SRNL as the SB5 flowsheet is further refined. A collection of several key criteria will provide the basis for the frit development and selection process. These include identifying frits that: provide reasonable projected operational windows over the anticipated SB5 composition region, are robust to anticipated sludge composition variation, improve or maintain high waste loadings, improve or maintain high melt rates, and have "frittable" compositions. Of particular interest will be the determination of waste throughput factors (melt rate versus waste loading trends) for select SB5 glass systems of interest. The primary mechanism to assess candidate SB5 frits will be a paper study using model-based predictions and current PCCS constraints.

Later frit development efforts will assess the viability of using the current $0.6 \mathrm{wt} \% \mathrm{SO}_{4}{ }^{2-}$ limit (in glass) and/or the possibility of increasing the $\mathrm{SO}_{4}{ }^{2-}$ solubility limit in PCCS to account for anticipated sulfur concentrations in SB5. If warranted, later studies may also assess the need to increase the $\mathrm{TiO}_{2}$ limit in PCCS to accommodate the MST streams. Other factors such as the potential formation of nepheline will also be assessed through paper study assessments and experimental studies. Melt rate assessments (utilizing both dry-fed and slurry-fed systems) will also be assessed for select systems of interest to support the frit recommendation process and to evaluate melt rate as a function of waste loading.

The preliminary study described in this report identifies candidate frits using the February 2007 SB5 composition projection from the Liquid Waste Organization (LWO), considering a sludge-only operational mode and without the implementation of aluminum dissolution. A paper study was used to select a small series of candidate frits for further study. In addition, the intent is to measure melt rates for these glass systems using SRNL's dry-fed melt rate furnace (MRF). Glass compositions are developed for the selected frits using the projected SB5 composition. These glasses are fabricated and characterized in the laboratory to verify that the durability and nepheline crystallization models used in the paper study are applicable to these glass systems.

This work is undertaken in response to a Technical Task Request issued by DWPF ${ }^{1}$ and is performed under a Task Technical and Quality Assurance Plan. ${ }^{2}$ 
WSRC-STI-2007-00418

Revision 0

This page intentionally left blank. 


\subsection{Experimental Procedure}

This section describes the strategy used to select the glasses for the study, including the target sludge and frit compositions. The target glass compositions are then given, followed by a discussion of the techniques used to fabricate and analyze the glasses.

\subsection{Frit Selection Strategy}

A projected composition for SB5 was received from LWO in February 2007. ${ }^{3}$ This projection did not include the impacts of implementing the aluminum dissolution process or the addition of ARP/MCU feed streams. The data were converted to an oxide basis and are shown in Table 2-1. Projected washing data were provided when the LWO report was issued. These data were used to project a $\mathrm{SO}_{4}{ }^{2-}$ concentration for the sludge, ${ }^{\mathrm{a}}$ which is also included in Table 2-1.

Table 2-1. Projected SB5 composition (in wt\% oxides), renormalized to exclude the radioactive components.

\begin{tabular}{|c|c|}
\hline $\begin{array}{c}\text { Sludge } \\
\text { Component }\end{array}$ & $\begin{array}{c}\text { Concentration } \\
\text { (wt \%) }\end{array}$ \\
\hline $\mathrm{Al}_{2} \mathrm{O}_{3}$ & 30.58 \\
\hline $\mathrm{B}_{2} \mathrm{O}_{3}$ & 0.00 \\
\hline $\mathrm{BaO}$ & 0.11 \\
\hline $\mathrm{CaO}$ & 2.09 \\
\hline $\mathrm{Ce}_{2} \mathrm{O}_{3}$ & 0.23 \\
\hline $\mathrm{Cr}_{2} \mathrm{O}_{3}$ & 0.20 \\
\hline $\mathrm{CuO}$ & 0.07 \\
\hline $\mathrm{Fe}_{2} \mathrm{O}_{3}$ & 24.30 \\
\hline $\mathrm{K}_{2} \mathrm{O}$ & 0.16 \\
\hline $\mathrm{La}_{2} \mathrm{O}_{3}$ & 0.03 \\
\hline $\mathrm{Li}_{2} \mathrm{O}$ & 0.00 \\
\hline $\mathrm{MgO}$ & 1.41 \\
\hline $\mathrm{MnO}_{\mathrm{Na} O} \mathrm{O}$ & 5.20 \\
\hline $\mathrm{Na}_{2} \mathrm{O}$ & 22.65 \\
\hline $\mathrm{NiO}_{\mathrm{PbO}}$ & 2.31 \\
\hline $\mathrm{SO}_{4}{ }^{2-}$ & 0.10 \\
\hline $\mathrm{SiO}_{2}$ & 1.16 \\
\hline $\mathrm{ThO}_{2}$ & 1.82 \\
\hline $\mathrm{TiO}_{2}$ & 0.01 \\
\hline $\mathrm{U}_{3} \mathrm{O}_{8}$ & 0.51 \\
\hline $\mathrm{ZnO}^{\mathrm{ZnO} O}$ & 6.75 \\
\hline & 0.07 \\
\hline
\end{tabular}

An array of frit compositions was next developed to be combined with this sludge at waste loadings (WLs) from $25 \%$ to $60 \%$. The frit components and their range of concentrations were selected based on previous experience with DWPF processing, and are listed in Table 2-2. Every combination of $\mathrm{B}_{2} \mathrm{O}_{3}, \mathrm{CaO}, \mathrm{Fe}_{2} \mathrm{O}_{3}, \mathrm{Li}_{2} \mathrm{O}, \mathrm{MgO}, \mathrm{Na}_{2} \mathrm{O}$ and $\mathrm{ZrO}_{2}$ within the concentration ranges given in Table 2-2 was used to develop frit compositions, with the $\mathrm{SiO}_{2}$ concentration making up the remainder of the mass. This resulted in a total of 14,580 frit compositions to be assessed.

\footnotetext{
a See WSRC-NB-2006-00017, pages 122-123 for details of the $\mathrm{SO}_{4}{ }^{2-}$ calculation.
} 
WSRC-STI-2007-00418

Revision 0

Table 2-2. Frit components and their concentration ranges used for MAR assessments.

\begin{tabular}{|c|c|c|}
\hline $\begin{array}{c}\text { Frit } \\
\text { Component }\end{array}$ & $\begin{array}{c}\text { Concentration } \\
\text { Range (wt\%) }\end{array}$ & $\begin{array}{c}\text { Increment } \\
\text { (wt \%) }\end{array}$ \\
\hline $\mathrm{B}_{2} \mathrm{O}_{3}$ & $12-20$ & 1 \\
\hline $\mathrm{CaO}$ & $0-2$ & 1 \\
\hline $\mathrm{Fe}_{2} \mathrm{O}_{3}$ & $0-2$ & 1 \\
\hline $\mathrm{Li}_{2} \mathrm{O}$ & $8-11$ & 1 \\
\hline $\mathrm{MgO}$ & $0-2$ & 1 \\
\hline $\mathrm{Na}_{2} \mathrm{O}$ & $0-4$ & 1 \\
\hline $\mathrm{SiO}_{2}$ & $57-80$ & 1 \\
\hline $\mathrm{ZrO}_{2}$ & $0-2$ & 1 \\
\hline
\end{tabular}

The paper assessment paired the sludge composition in Table 2-1 with the 14,580 frit compositions described by Table 2-2 and applied the PCCS Measurement Acceptability Region (MAR) criteria to determine which combinations would produce acceptable glasses (based on model predictions) over the range of WLs from $25 \%$ to $60 \%$. The $\mathrm{SO}_{4}{ }^{2-}$ limit of $0.6 \mathrm{wt} \%$ in glass was not activated in the MAR. Other constraints are expected to limit the achievable WL before the $\mathrm{SO}_{4}{ }^{2-}$ limit is reached for this SB5 projection (1.24 wt $\% \mathrm{SO}_{4}{ }^{2-}$ in sludge) since the $0.60 \mathrm{wt} \% \mathrm{SO}_{4}{ }^{2-}$ limit would not be exceed until a WL of $48 \%$. The MAR assessment results for six selected frits are shown in Table 2-3. These six frits were selected based on their relatively wide range of waste loadings over which an acceptable glass was predicted, their relatively high concentrations of $\mathrm{B}_{2} \mathrm{O}_{3}$ (which is likely to both improve melt rate and suppress nepheline crystallization), and in the case of Frit 510, its use in processing Sludge Batch 4.

Table 2-3. Composition of the six frits selected for MRF testing (in wt \% oxides) and their MAR assessment results.

\begin{tabular}{||c|c|c|c|c|c|c||}
\hline \hline Frit ID & $\mathbf{B}_{\mathbf{2}} \mathbf{O}_{\mathbf{3}}$ & $\mathbf{L i}_{\mathbf{2}} \mathbf{O}$ & $\mathbf{N a}_{\mathbf{2}} \mathbf{O}$ & $\mathbf{S i O}_{\mathbf{2}}$ & WL Range (wt \%) & Limiting Constraint \\
\hline 503 & 14 & 8 & 4 & 74 & $25-42$ & Nepheline \\
\hline 510 & 14 & 8 & 8 & 70 & $25-38$ & Nepheline \\
\hline 516 & 14 & 11 & 2 & 73 & $25-43$ & $\mathrm{~T}_{\mathrm{L}}$, Nepheline \\
\hline 517 & 17 & 10 & 3 & 70 & $25-42$ & $\mathrm{~T}_{\mathrm{L}}$, Nepheline \\
\hline 518 & 20 & 10 & 1 & 69 & $25-39$ & $\mathrm{~T}_{\mathrm{L}}$ \\
\hline 519 & 20 & 9 & 3 & 68 & $25-41$ & $\mathrm{~T}_{\mathrm{L}}$, Nepheline \\
\hline
\end{tabular}

For the six selected frits, the upper end of the WL range was limited by either predictions of nepheline crystallization, a high liquidus temperature $\left(\mathrm{T}_{\mathrm{L}}\right)$, or both. Frit 518 was the only system that was not limited by a wasteform-affecting constraint (nepheline crystallization was not a limiting constraint until 44\% WL). ${ }^{a}$ The six frits cover a wide range of $\mathrm{B}_{2} \mathrm{O}_{3}$ concentrations (14-20 wt\%) and $\mathrm{Na}_{2} \mathrm{O}$ concentrations (1-8 wt\%), which should provide the ability to evaluate the influence of these components on the measured melt rate for the February 2007 SB5 system.

\footnotetext{
${ }^{a}$ Nepheline crystallization is considered a wasteform-affecting constraint due to its adverse impact on durability of the glass. Liquidus temperature is considered a process-affecting constraint due to concerns over the accumulation of crystalline material within the melter.
} 


\subsection{Target Glass Compositions}

Crucible-scale glass melts were used to measure the durability of glasses produced with the six selected frits as well as to determine whether any crystallization issues exist for glasses that are slowly cooled. The frits were combined with the projected SB5 composition at a WL of 36\% (slightly above the DWPF target of 34\% for SB5) to develop the target test glass compositions, which are given in Table 2-4. Note that the sludge composition given in Table 2-4 was renormalized to remove the radioactive components ( $\mathrm{U}$ and $\mathrm{Th}$ ) in order to simplify laboratory experiments.

Table 2-4. Target compositions of the six test glasses (in wt \% oxides).

\begin{tabular}{|c|c|c|c|c|c|c|}
\hline Glass ID & SB5MR-503 & SB5MR-510 & SB5MR-516 & SB5MR-517 & SB5MR-518 & SB5MR-519 \\
\hline Frit & 503 & 510 & 516 & 517 & 518 & 519 \\
\hline WL & 36 & 36 & 36 & 36 & 36 & 36 \\
\hline $\mathrm{Al}_{2} \mathbf{O}_{3}$ & 11.81 & 11.81 & 11.81 & 11.81 & 11.81 & 11.81 \\
\hline $\mathbf{B}_{2} \mathbf{O}_{3}$ & 8.96 & 8.96 & 8.96 & 10.88 & 12.80 & 12.80 \\
\hline BaO & 0.04 & 0.04 & 0.04 & 0.04 & 0.04 & 0.04 \\
\hline $\mathrm{CaO}$ & 0.81 & 0.81 & 0.81 & 0.81 & 0.81 & 0.81 \\
\hline $\mathrm{Ce}_{2} \mathrm{O}_{3}$ & 0.09 & 0.09 & 0.09 & 0.09 & 0.09 & 0.09 \\
\hline $\mathrm{Cr}_{2} \mathrm{O}_{3}$ & 0.08 & 0.08 & 0.08 & 0.08 & 0.08 & 0.08 \\
\hline $\mathrm{CuO}$ & 0.03 & 0.03 & 0.03 & 0.03 & 0.03 & 0.03 \\
\hline $\mathrm{Fe}_{2} \mathrm{O}_{3}$ & 9.38 & 9.38 & 9.38 & 9.38 & 9.38 & 9.38 \\
\hline $\mathbf{K}_{2} \mathbf{O}$ & 0.06 & 0.06 & 0.06 & 0.06 & 0.06 & 0.06 \\
\hline $\mathrm{La}_{2} \mathbf{O}_{3}$ & 0.01 & 0.01 & 0.01 & 0.01 & 0.01 & 0.01 \\
\hline $\mathbf{L i}_{2} \mathbf{O}$ & 5.12 & 5.12 & 7.04 & 6.40 & 6.40 & 5.76 \\
\hline MgO & 0.55 & 0.55 & 0.55 & 0.55 & 0.55 & 0.55 \\
\hline $\mathrm{MnO}$ & 2.01 & 2.01 & 2.01 & 2.01 & 2.01 & 2.01 \\
\hline $\mathrm{Na}_{2} \mathrm{O}$ & 11.30 & 13.86 & 10.02 & 10.66 & 9.38 & 10.66 \\
\hline $\mathrm{NiO}$ & 0.89 & 0.89 & 0.89 & 0.89 & 0.89 & 0.89 \\
\hline PbO & 0.04 & 0.04 & 0.04 & 0.04 & 0.04 & 0.04 \\
\hline $\mathrm{SO}_{4}{ }^{2-}$ & 0.45 & 0.45 & 0.45 & 0.45 & 0.45 & 0.45 \\
\hline $\mathrm{SiO}_{2}$ & 48.06 & 45.50 & 47.42 & 45.50 & 44.86 & 44.22 \\
\hline $\mathrm{ThO}_{2}$ & 0.00 & 0.00 & 0.00 & 0.00 & 0.00 & 0.00 \\
\hline $\mathrm{TiO}_{2}$ & 0.20 & 0.20 & 0.20 & 0.20 & 0.20 & 0.20 \\
\hline $\mathbf{U}_{3} \mathbf{O}_{\mathbf{8}}$ & 0.00 & 0.00 & 0.00 & 0.00 & 0.00 & 0.00 \\
\hline $\mathrm{ZnO}$ & 0.03 & 0.03 & 0.03 & 0.03 & 0.03 & 0.03 \\
\hline $\mathrm{ZrO}_{2}$ & 0.09 & 0.09 & 0.09 & 0.09 & 0.09 & 0.09 \\
\hline Total & 100.00 & 100.00 & 100.00 & 100.00 & 100.00 & 100.00 \\
\hline
\end{tabular}

\subsection{Glass Fabrication}

Each study glass was prepared from the proper proportions of reagent-grade metal oxides, carbonates, $\mathrm{H}_{3} \mathrm{BO}_{3}$, and salts in $150 \mathrm{~g}$ batches. ${ }^{4}$ The raw materials were thoroughly mixed and placed into a 95\% platinum / 5\% gold, $250 \mathrm{ml}$ crucible. The batch was placed into a high-temperature furnace at the target melt temperature of $1150{ }^{\circ} \mathrm{C} .{ }^{5}$ The crucible was removed from the furnace after an isothermal hold at $1150{ }^{\circ} \mathrm{C}$ for 1 hour. The glass was poured onto a clean, stainless steel plate and allowed to air cool (quench). The glass pour patty was used as a sampling stock for the various property measurements, including durability testing.

Approximately $25 \mathrm{~g}$ of each glass was heat-treated to simulate cooling along the centerline of a DWPF-type canister ${ }^{6}$ to gauge the effects of thermal history on the product performance. This 
cooling schedule is referred to as the ccc curve. Visual observations on both quenched and ccc glasses were recorded.

\subsection{Property Measurements}

This section provides a general discussion of the Product Consistency Test results and the X-ray diffraction analyses of the melter test glasses.

\subsubsection{Product Consistency Test}

The Product Consistency Test (PCT) ${ }^{7}$ was performed in triplicate on each quenched and ccc glass to assess chemical durability. Also included in the experimental test matrix was the Environmental Assessment (EA) glass, ${ }^{8}$ the Approved Reference Material (ARM) glass, and blanks from the sample cleaning batch. Samples were ground, washed, and prepared according to the standard procedure. ${ }^{7}$ Fifteen milliliters of Type I ASTM water were added to $1.5 \mathrm{~g}$ of glass in stainless steel vessels. The vessels were closed, sealed, and placed in an oven at $90 \pm 2{ }^{\circ} \mathrm{C}$, where the samples were maintained at temperature for 7 days. Once cooled, the resulting solutions were sampled (filtered and acidified), then labeled and analyzed by the Process Science Analytical Laboratory (PSAL) using inductively coupled plasma - atomic emission spectroscopy (ICP-AES). Normalized release rates were calculated based on target compositions using the average of the common logarithms of the leachate concentrations.

\subsubsection{X-Ray Diffraction Analysis}

Visual observations for crystallization were performed and documented for all of the glasses. Since some of the ccc glasses were observed to contain small amounts of crystals, representative samples for all of the ccc glasses were submitted to SRNL Analytical Development (AD) for X-ray diffraction (XRD) analysis. Samples were analyzed under conditions providing a detection limit of approximately $0.5 \mathrm{vol} \%$. That is, if a crystalline phase were present at $0.5 \mathrm{vol} \%$ or greater, the diffractometer would not only be capable of detecting the crystals but would also allow a qualitative determination of the type of crystal(s) present. Otherwise, a characteristically high background devoid of crystalline spectral peaks indicates that the glass product is amorphous, suggesting either a completely amorphous product or that the degree of crystallization is below the detection limit. 


\subsection{Results and Discussion}

This section discusses visual observations of the glasses after fabrication, the results of XRD analyses and the results of the PCT for each glass, both quenched and ccc. The initial results of dry-fed melt rate testing are briefly presented.

\subsection{Homogeneity}

Visual observations of each glass were recorded after melting and quenching, as well as at the completion of the ccc heat treatment. These observations are listed in Table 3-1. The term 'clean' means that no crystallization was visually observed in the glass. A typical DWPF composition glass will also appear 'black and shiny,' which again indicates the lack of any visible crystallization.

Table 3-1. Visual observations and XRD results for the quenched and ccc version of each glass.

\begin{tabular}{||c|c|l|c||}
\hline \hline Glass ID & Heat Treatment & \multicolumn{1}{|c||}{ Visual Observations } & XRD \\
\hline \multirow{2}{*}{ SB5MR-503 } & quenched & clean, black and shiny & - \\
\cline { 2 - 4 } & CCC & slight haze with scattered surface crystals; bulk clean & magnetite \\
\hline \multirow{2}{*}{ SB5MR-510 } & quenched & clean, black and shiny & - \\
\cline { 2 - 4 } & CCC & slight haze, small crystals on surface; bulk clean & magnetite \\
\hline \multirow{2}{*}{ SB5MR-516 } & quenched & clean, black and shiny & - \\
\cline { 2 - 4 } & CCC & some crystals on surface; bulk clean & magnetite \\
\hline \multirow{2}{*}{ SB5MR-517 } & quenched & clean, black and shiny & magnetite \\
\cline { 2 - 4 } & CCC & crystals on surface; bulk clean & - \\
\hline \multirow{2}{*}{ SB5MR-518 } & quenched & clean, black and shiny & magnetite \\
\cline { 2 - 4 } & CCC & crystals on surface; bulk clean & magnetite \\
\hline \multirow{2}{*}{ SB5MR-519 } & quenched & clean, black and shiny & crystals on surface; bulk clean \\
\cline { 2 - 4 } & CCC & &
\end{tabular}

The quenched versions of each glass appeared visually amorphous. Some crystallization was visible on the surface of each of the ccc versions of the glasses, but no crystallization was visible along the cross-section of the ccc samples (i.e., the 'bulk' of the glass). XRD was used to determine the type of crystallization present in each of the ccc glasses. The crystalline phase was identified as magnetite for all six of the test glasses. The small amount of magnetite present in each glass is unlikely to impact the glasses' durability after the ccc heat treatment. This will be confirmed by the results of the PCTs.

\subsection{Product Consistency Test}

The PCT was completed for each of the six test glasses, both quenched and ccc. The ARM and EA standard glasses were also included in the tests. The results of the PCTs, normalized to the target glass compositions, are given in Table 3-2. 
WSRC-STI-2007-00418

Revision 0

Table 3-2. PCT results for each of the test glasses and the standards.

\begin{tabular}{|c|c|c|c|c||}
\hline \multirow{2}{*}{ Glass ID } & \multicolumn{4}{|c|}{ Normalized Release (g/L) } \\
\cline { 2 - 5 } & $\mathbf{L i}$ & $\mathbf{B}$ & $\mathbf{N a}$ & $\mathbf{S i}$ \\
\hline ARM & 0.53 & 0.45 & 0.45 & 0.26 \\
\hline EA & 9.46 & 17.76 & 14.82 & 4.01 \\
\hline SB5MR-503 & 0.59 & 0.51 & 0.44 & 0.37 \\
\hline SB5MR-503ccC & 0.56 & 0.46 & 0.44 & 0.36 \\
\hline SB5MR-510 & 0.57 & 0.53 & 0.63 & 0.40 \\
\hline SB5MR-510ccC & 0.59 & 0.53 & 0.61 & 0.40 \\
\hline SB5MR-516 & 0.66 & 0.58 & 0.53 & 0.43 \\
\hline SB5MR-516ccC & 0.66 & 0.57 & 0.54 & 0.44 \\
\hline SB5MR-517 & 0.63 & 0.56 & 0.52 & 0.40 \\
\hline SB5MR-517ccC & 0.65 & 0.58 & 0.55 & 0.43 \\
\hline SB5MR-518 & 0.67 & 0.61 & 0.46 & 0.40 \\
\hline SB5MR-518ccC & 0.61 & 0.55 & 0.46 & 0.38 \\
\hline SB5MR-519 & 0.63 & 0.57 & 0.48 & 0.38 \\
\hline SB5MR-519ccC & 0.63 & 0.58 & 0.50 & 0.39 \\
\hline \hline \multicolumn{4}{|c|}{}
\end{tabular}

The measured values for the ARM glass fall within the specified control limits. ${ }^{9}$ Note that the normalized release for boron for the EA glass is slightly above the typical value of $16.695 \mathrm{~g} / \mathrm{L}{ }^{8}$

The PCT results for the six study glasses show that each glass has a durability that is considered very acceptable, with normalized releases for boron that are better than an order of magnitude below that of the EA glass. There is little difference between the PCT responses of the quenched and ccC versions of each glass, indicating that the small amount of crystallization identified in the ccc glasses by visual observation and XRD has no measurable impact on durability. In terms of durability, any of the six frits tested would produce an acceptable glass with the given sludge composition and waste loading.

\subsection{Model Applicability}

The PCT results were compared with the durabilities predicted by the free energy of hydration, or $\Delta \mathrm{G}_{\mathrm{P}}$ model $^{9}$ to evaluate the applicability of the model (which is used as part of the DWPF process control system) to the SB5 composition projection and frits used in this study. The results of this comparison are shown in Figure 3-1. 
$\log \mathrm{NL}[\mathrm{B}(\mathrm{g} / \mathrm{L})]$ by $\Delta \mathrm{G}_{\mathrm{P}}$

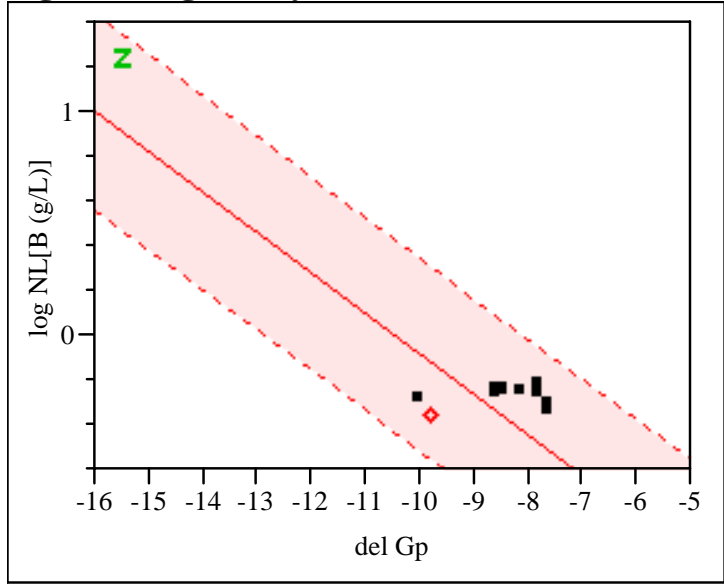

$\log \mathrm{NL}[\mathrm{Li}(\mathrm{g} / \mathrm{L})]$ by $\Delta \mathrm{G}_{\mathrm{P}}$

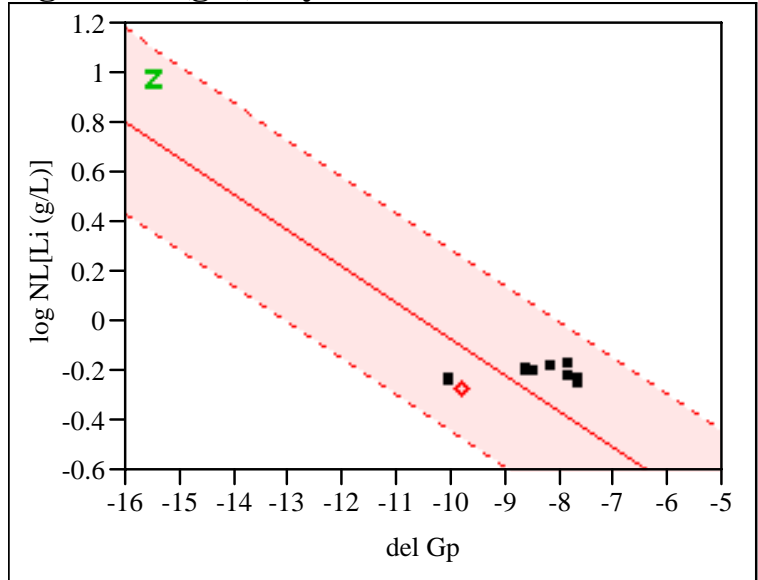

$\log \mathrm{NL}[\mathrm{Na}(\mathrm{g} / \mathrm{L})]$ by $\Delta \mathrm{G}_{\mathbf{P}}$

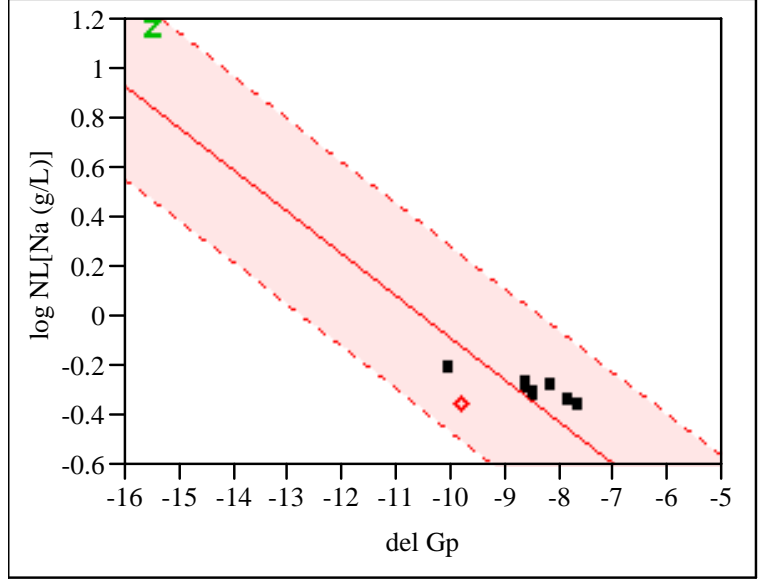

$\log \mathrm{NL}[\mathrm{Si}(\mathrm{g} / \mathrm{L})]$ by $\Delta \mathrm{G}_{\mathrm{P}}$

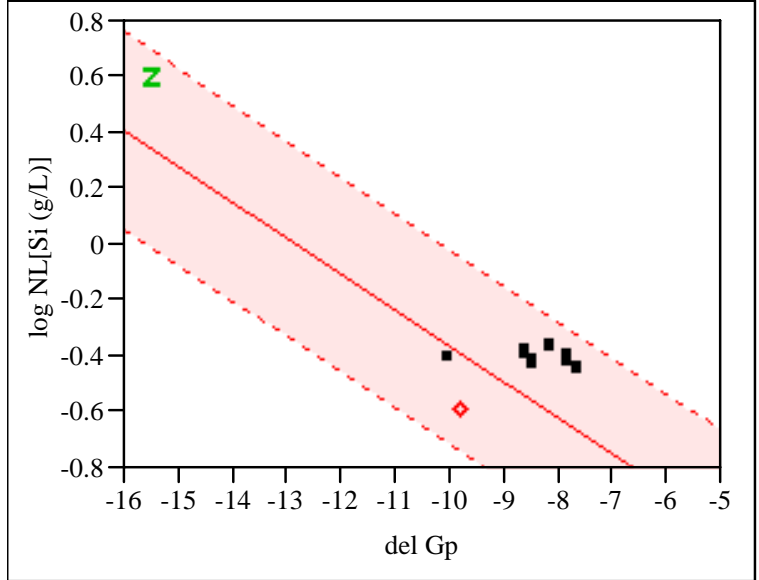

Figure 3-1. Comparison of the Measured PCT Responses and the Durabilities Predicted by the Free Energy of Hydration Model.

The solid red lines in the plots of Figure 3-1 indicate the predicted durability with respect to a particular element (B, Na, Li or Si) based on the calculated $\Delta \mathrm{G}_{\mathrm{p}}$. The red shaded area indicates the $95 \%$ confidence bounds on the prediction for an individual glass. The measured durabilities of the ARM and EA standard glasses are indicated on these plots by the red and green data points, respectively. The durabilities of the SB5 glasses in this study, measured by the PCT, are indicated by the black data points in Figure 3-1. All of these points fall within the bounds of the model predictions, indicating that the $\Delta \mathrm{G}_{\mathrm{P}}$ model is applicable to the evaluated frit/sludge systems.

\subsection{Initial Melt Rate Results}

A full report on the dry-fed MRF results is forthcoming; however, the initial results will be described briefly here. Each of the six frits was combined with a dry Slurry Receipt and Adjustment Tank (SRAT) product corresponding to the sludge composition listed in Table 2-1 at 35\% WL. The feeds were then melted in the MRF for 50 minutes at $1150{ }^{\circ} \mathrm{C}$. The crucibles were then cut in cross section, and the thickness of the melted glass layer was measured. Two MRF runs were completed. The first included all six of the test frits. The results are given in Table 3-3. A second round of MRF testing was run using the best performing frits from the first run. These results are also given in Table 3-3. 
WSRC-STI-2007-00418

Revision 0

Table 3-3. Melt rate results for the six frits.

\begin{tabular}{|c|c|c|c|c||}
\hline \multirow{2}{*}{ Glass ID } & \multicolumn{2}{|c|}{ Melt Rate (in/hr) } & \multicolumn{2}{c|}{ Components in Frit (wt\%) } \\
\cline { 2 - 5 } & Run \#1 & Run \#2 & $\mathbf{B}_{\mathbf{2}} \mathbf{O}_{\mathbf{3}}$ & $\mathbf{N a}_{\mathbf{2}} \mathbf{O}$ \\
\hline SB5MR-503 & 0.52 & 0.40 & 14 & 4 \\
\hline SB5MR-510 & 0.47 & - & 14 & 8 \\
\hline SB5MR-516 & 0.47 & - & 14 & 2 \\
\hline SB5MR-517 & 0.56 & 0.48 & 17 & 3 \\
\hline SB5MR-518 & 0.49 & - & 20 & 3 \\
\hline SB5MR-519 & 0.53 & 0.60 & 20 & 8 \\
\hline $\begin{array}{c}\text { Frit 418 Standard, } \\
\text { First Layer }\end{array}$ & 1.48 & 1.53 & 8 & 8 \\
\hline $\begin{array}{c}\text { Frit 418 Standard, } \\
\text { Second Layer }\end{array}$ & 3.18 & 3.23 & 8 & \\
\hline
\end{tabular}

In general, the MRF testing results show that as the concentration of $\mathrm{B}_{2} \mathrm{O}_{3}$ in the frit increases, melt rate also increases. This trend is consistent with that observed in dry-fed and slurry-fed melt rate tests with SB4 - another high $\mathrm{Al}_{2} \mathrm{O}_{3}$ waste stream. ${ }^{10}$ The impact of $\mathrm{Na}_{2} \mathrm{O}$ concentration on melt rate is not clear from these results. Note that the Frit 418 Standard is a frit-only test (i.e., without any sludge addition) and therefore shows a considerably higher melt rate. Further data analysis for the MRF testing is underway, and the results will be more thoroughly discussed in a subsequent report. 


\subsection{Summary}

Six potential frits were identified as candidates processing the February 2007 projected SB5 composition based upon MAR assessments of this sludge and an array of frit compositions. Test glasses were fabricated in the laboratory to verify the applicability of the product performance models to glasses produced with these frits.

Characterization of the glasses fabricated with the selected frits showed that all of the glasses had durability responses that are considered very acceptable and predictable by the free energy of hydration model. No crystallization was identified in the quenched glasses. Samples of the glasses that were slowly cooled following the canister centerline cooled (cсc) thermal profile were found to contain small amounts of magnetite. This crystalline phase had little impact on the durability of the glasses, and therefore is not an issue for concern.

Initial melt rate testing results showed that the previously identified trend of increasing melt rate with increasing concentration of $\mathrm{B}_{2} \mathrm{O}_{3}$ may be extended to this $\mathrm{SB} 5$ system. A complete report on melt rate testing with these frits will be issued at a later date. 
WSRC-STI-2007-00418

Revision 0

This page intentionally left blank. 


\subsection{Path Forward}

- The results of the MRF testing will be more thoroughly discussed in a subsequent report.

- Subsequent MAR assessments will be performed on revised SB5 compositional projections as washing or blending strategies change or as the Al-dissolution flowsheet evolves.

- Additional melt rate testing should be undertaken when an updated SB5 composition projection is received from LWO.

- If the aluminum dissolution process will be implemented for SB5 processing, additional melt rate testing should be performed based on the estimated impacts of aluminum dissolution to the SB5 flowsheet. 
WSRC-STI-2007-00418

Revision 0

This page intentionally left blank. 
WSRC-STI-2007-00418

Revision 0

\subsection{References}

1. Culbertson, B. H., "Sludge Batch 5 Frit Optimization,” U.S. Department of Energy Report HLWDWPF-TTR-2007-0007, Revision 0, Washington Savannah River Company, Aiken, SC (2006).

2. Peeler, D. K., “Sludge Batch 5 Frit Optimization,” U.S. Department of Energy Report WSRC-STI2006-00321, Washington Savannah River Company, Aiken, SC (2007).

3. Shah, H. B., "Estimate of Sludge Batch 4 and 5 Sludge Calcine Compositions for SRNL," U.S. Department of Energy Report LWO-PIT-2007-00017, Washington Savannah River Company, Aiken, SC (2007).

4. SRNL, "Glass Batching,” SRTC Procedure Manual, L29, ITS-0001, Westinghouse Savannah River Company, Aiken, SC (2002).

5. SRNL, “Glass Melting,” SRTC Procedure Manual, L29, ITS-0003, Westinghouse Savannah River Company, Aiken, SC (2002).

6. Marra, S. L. and C. M. Jantzen, "Characterization of Projected DWPF Glass Heat Treated to Simulate Canister Centerline Cooling,” U.S. Department of Energy Report WSRC-TR-92-142, Revision 1, Westinghouse Savannah River Company, Aiken, SC (1993).

7. ASTM, "Standard Test Methods for Determining Chemical Durability of Nuclear Waste Glasses: The Product Consistency Test (PCT),” ASTM C-1285, (2002).

8. Jantzen, C. M., N. E. Bibler, D. C. Beam, C. L. Crawford and M. A. Pickett, "Characterization of the Defense Waste Processing Facility (DWPF) Environmental Assessment (EA) Glass Standard Reference Material," U.S. Department of Energy Report WSRC-TR-92-346, Revision 1, Westinghouse Savannah River Company, Aiken, SC (1993).

9. Jantzen, C. M., J. B. Picket, K. G. Brown, T. B. Edwards and D. C. Beam, "Process/Product Models for the Defense Waste Processing Facility (DWPF): Part I. Predicting Glass Durability from Composition Using a Thermodynamic Hydration Energy Reaction Model (THERMO)," U.S. Department of Energy Report WSRC-TR-93-672, Revision 1, Westinghouse Savannah River Company, Aiken, SC (1995).

10. Peeler, D. K., T. B. Edwards and K. M. Fox, "Delaying the SB4 Transfer: An Assessment of the Impact on the Frit Recommendation and the Variability Study," U.S. Department of Energy Report SRNL-PSE-2007-00066, Washington Savannah River Company, Aiken, SC (2007). 